Article

\title{
Application of Electrodialysis for the Selective Lithium Extraction towards Cobalt, Nickel and Manganese from Leach Solutions Containing High Divalent Cations/Li Ratio
}

\author{
Soumaya Gmar ${ }^{1,2}$, Alexandre Chagnes ${ }^{1, * \mathbb{D}}$, Florence Lutin ${ }^{3}$ and Laurence Muhr ${ }^{2, *}$ \\ 1 Université de Lorraine, CNRS, GeoRessources, 54000 Nancy, France; soumaya.gmar@univ-lorraine.fr \\ 2 Université de Lorraine, CNRS, LRGP, 54000 Nancy, France \\ 3 Eurodia Industrie, Impasse Saint Martin, ZAC Saint Martin, 84120 Pertuis, France; florence.lutin@eurodia.com \\ * Correspondence: alexandre.chagnes@univ-lorraine.fr (A.C.); laurence.muhr@univ-lorraine.fr (L.M.); \\ Tel.: +33-372-744-544 (A.C.); +33-372-743-745 (L.M.)
}

check for

updates

Citation: Gmar, S.; Chagnes, A.;

Lutin, F.; Muhr, L. Application of Electrodialysis for the Selective

Lithium Extraction towards Cobalt, Nickel and Manganese from Leach

Solutions Containing High Divalent Cations/Li Ratio. Recycling 2022, 7,

14. https://doi.org/10.3390/

recycling7020014

Academic Editor: Ana Paula Paiva

Received: 8 January 2022

Accepted: 20 February 2022

Published: 2 March 2022

Publisher's Note: MDPI stays neutral with regard to jurisdictional claims in published maps and institutional affiliations.

Copyright: () 2022 by the authors Licensee MDPI, Basel, Switzerland. This article is an open access article distributed under the terms and conditions of the Creative Commons Attribution (CC BY) license (https:// creativecommons.org/licenses/by/ $4.0 /)$.

\begin{abstract}
The present work aims at investigating the potentialities of implementation of electrodialysis for the recycling of spent lithium-ion batteries. In this work, the use of highly-selective membrane toward lithium(I) in electrodialysis was investigated to recover selectively lithium(I) toward cobalt(II), nickel(II) and manganese(II) by means of monovalent ion-selective membranes. It was shown that the presence of divalent cations in the leach solution is responsible for a significant decrease of the limiting current despite an increase in ionic conductivity. Therefore, monitoring the ionic conductivity was not sufficient to operate electrodialysis under optimal conditions, especially when highly selective membranes were used. Furthermore, it was demonstrated that the current has to be lower than the limiting current to avoid metal hydroxide precipitation into the membrane porosity by monitoring the limiting current over time.
\end{abstract}

Keywords: lithium extraction; electrodialysis; lithium-ion battery recycling

\section{Introduction}

The energy transition relies on the development of technologies that make it possible to produce energy in a sustainable manner from resources such as wind, sun, potential energy, etc. The energy produced as part of the energy transition is often intermittent, and it is, therefore, necessary to be able to store and restore it reversibly. Electric mobility is also a major contributor to reducing the impacts of human activity on the environment and the climate since it contributes to reducing greenhouse gas emissions. Lithium-ion batteries (LiBs) are at the heart of energy storage for stationary applications and for electric mobility (electric vehicles, EVs) [1,2]. They are now widely used in phones, laptops, portable tools, etc., and their increasing use in EVs is indisputable (about 3 million new electric cars were registered in 2020 including 1.4 million new registrations in Europe despite the pandemic [3]). It is expected that this market (and the associated LiBs market) will continue to grow in the next decades under the impulsion of the energy transition and since EV prices will reach parity with fossil fuel-powered autos in 2025. Lithium is mainly extracted from primary resources such as ores (spodumene, lepidolite, petalite and amblyogonite) and brines [4-6]. Although mining is essential to meet the raw material demand for LiBs production, recycling can contribute to face up the future demand in lithium, cobalt, nickel, manganese and graphite arising from the huge increase in electric vehicle production in the next decade (for LiBs application, the cobalt, nickel and lithium demand is forecasted to increase by $180 \%, 900 \%$ and $1000 \%$ between 2019 and 2030, respectively [3]).

Currently, the recycling of lithium-ion batteries is carried out by pyrometallurgy [7] but more and more hydrometallurgical processes are developed [8,9]. The pyrometallurgical processes consist in putting lithium-ion batteries usually without preliminary dismantling 
in furnace at high temperature (around $1400{ }^{\circ} \mathrm{C}$ ), leading to the production of a slag containing lithium and aluminum, and an alloy containing copper, iron, nickel, manganese and cobalt, which can be processed by hydrometallurgy. The hydrometallurgical route relies on deep-discharge, dismantling, grinding, leaching and selective extraction of metals by means of ion-exchange resins, solvent extraction and/or precipitation. The pyrometallurgy route is energy-intensive, responsible for loss of valuable metals in slags, loss of graphite as $\mathrm{CO}_{2}$ and is unable to separate metals directly whereas hydrometallurgical technologies are selective, less energy-consuming and allow reducing of production of effluents [5]. Many researches focused on the investigation of alternative unit operations to improve the recycling process efficiency while reducing the process cost and the environmental impact. For instance, the development of unit operations based on the use of microorganismsultrawave, deep-eutectic solvents to leach cathodic materials as well as ionic liquidsdeep-eutectic solvents or supercritical fluids to extract and separate valuable metals from cathodic materials, are under investigation [10-13]. Electrodialysis (ED) is another relevant technology which is widely used in desalination processes [14,15]. This technology may advantageously reduce the environmental impact, the capital expenditure and operation expenditure of hydrometallurgical processes. However, few studies concern its use in hydrometallurgical processes, and even less address the use of ED in lithium-ion battery recycling processes $[13,16-18]$

Lizuka et al. [16] showed that the use of Selemion CMV cation exchange membrane and BP-1E bipolar membrane in electrodializer allowed in recovering selectively $99 \%$ lithium(I) from a leaching solution containing $138.82 \mathrm{mg} \mathrm{L}^{-1}$ lithium(I) and $1.179 \mathrm{~g} \mathrm{~L}^{-1}$ cobalt(II) produced by digesting $\mathrm{LiCoO}_{2}$ in $1 \mathrm{~mol} \mathrm{~L}^{-1}$ nitric acid in the presence of 0.8 (vol) \% of $\mathrm{H}_{2} \mathrm{O}_{2}$, providing that cobalt(II) was previously complexed by ethylenediaminetetraacetic acid (EDTA) at $\mathrm{pH}=4$. Likewise, Afifah et al. [17] studied the lithium(I)-cobalt(II) separation in nitric acid by electrodialysis by using five pairs of monovalent selective ions exchange membranes (PC Cell membranes PC-MVK/PC-MVA). The separation efficiency was about $99 \%$ and a purity of $95.7 \%$ was achieved by applying $3 \mathrm{~V} /$ cell and a flowrate of $15 \mathrm{~L} \mathrm{~h}^{-1}$. Song and Zhao (2018) [16] combined precipitation and electrodialysis operations to produce lithium carbonate from acidic sulfate solution at $\mathrm{pH} 4.1$ containing $3.25 \mathrm{~g} \mathrm{~L}^{-1} \mathrm{Li}$, $0.25 \mathrm{~g} \mathrm{~L}^{-1} \mathrm{Co}, 0.28 \mathrm{~g} \mathrm{~L}^{-1} \mathrm{Mn}, 0.25 \mathrm{~g} \mathrm{~L}^{-1} \mathrm{Ni}, 90 \mathrm{~g} \mathrm{~L}^{-1} \mathrm{SO}_{4}{ }^{2-}, 0.23 \mathrm{~g} \mathrm{~L}^{-1} \mathrm{Al}, 0.46 \mathrm{~g} \mathrm{~L}^{-1} \mathrm{Ca}$, $0.68 \mathrm{~g} \mathrm{~L}^{-1} \mathrm{Cu}, 0.57 \mathrm{~g} \mathrm{~L}^{-1} \mathrm{Fe}, 0.79 \mathrm{~g} \mathrm{~L}^{-1} \mathrm{Mg}, 0.78 \mathrm{~g} \mathrm{~L}^{-1} \mathrm{Zn}, 17.5 \mathrm{~g} \mathrm{~L}^{-1} \mathrm{Cl}$ and $34 \mathrm{~g} \mathrm{~L}^{-1}$ $\mathrm{Na}$. Firstly, $\mathrm{NaOH}$ was used to precipitate $\mathrm{Ca}, \mathrm{Mg}, \mathrm{Mn}, \mathrm{Ni}, \mathrm{Co}, \mathrm{Zn}, \mathrm{Fe}, \mathrm{Al}$ and $\mathrm{Cu}$ at $\mathrm{pH}=12$. Lithium(I) was then precipitated as lithium phosphate by using sodium phosphate. Afterwards, lithium phosphate was dissolved in sulfuric acid. ED with a Nafion 117 cation exchange membrane was used to separate lithium(I) and phosphorus from the resulting solution. Sodium carbonate was added into the resulting solution containing lithium(I) to precipitate lithium carbonate (purity $=99.3 \%$ ). Chan et al. (2022) [13] studied lithium(I)-cobalt(II)-nickel(II)-manganese(II) separation from the leach solution containing $69.41 \mathrm{mg} \mathrm{L}^{-1} \mathrm{Li}(\mathrm{I}), 195.43 \mathrm{mg} \mathrm{L}^{-1} \mathrm{Ni}(\mathrm{II}), 182.91 \mathrm{mg} \mathrm{L}^{-1} \mathrm{Mn}$ (II) and $196.24 \mathrm{mg} \mathrm{L}^{-1} \mathrm{Co}(\mathrm{II})$, produced by digesting $\mathrm{LiNi}_{1 / 3} \mathrm{Mn}_{1 / 3} \mathrm{Co}_{1 / 3} \mathrm{O}_{2}$ (NMC111) in $1 \mathrm{~mol} \mathrm{~L}^{-1} \mathrm{H}_{2} \mathrm{SO}_{4}$ in the presence of $0.62 \%(w t) \mathrm{H}_{2} \mathrm{O}_{2}$. Around $99 \%$ nickel was recovered by ED after complexation with EDTA at $\mathrm{pH}=2$. Likewise, $87.3 \%$ cobalt was recovered at $\mathrm{pH}=3$ by ED in a second step, and ED was performed to separate lithium(I) from manganese(II) by means of the monovalent selective cation exchange membrane Neosepta ${ }^{\circledR}$ CMS (separation yield $=99 \%$ ).

Therefore, only several papers were focused on the use of electrodialysis to separate lithium(I), cobalt(II), nickel(II) and manganese(II) in acidic sulfate media without the use of additives such as chelating agents, which avoid precipitation phenomena during electrodialysis [13]. The present paper investigates the separation of lithium(I) from manganese(II), nickel(II) and cobalt(II) in acid sulfate media even at relatively low $\mathrm{pH}$ by means of electrodialysis using two commercial membranes, i.e., Neosept ${ }^{\circledR}$ monovalent-selective cation exchange membrane and CSO cationic exchange membrane. Based on these results, a hybrid flowsheet relying on the use of electrodialysis, solvent extraction and precip- 
itation stages was suggested to concentrate and refine the lithium streams from spent $\mathrm{LiCo}_{1 / 3} \mathrm{Ni}_{1 / 3} \mathrm{Mn}_{1 / 3} \mathrm{O}_{2}$ (NMC111) cathodes of lithium-ion batteries.

\section{Materials and Methods}

\subsection{Reagents}

The aqueous solutions and the synthetic leach solution were prepared by dissolving appropriate amounts of reagents into deionized water (resistivity $=18 \mathrm{Mohms}$ ), i.e., $\mathrm{Li}_{2} \mathrm{SO}_{4}$ (Aldrich, Saint Louis, MO, USA, purity $\geq 98.5 \%$ ), $\mathrm{CoSO}_{4} .7 \mathrm{H}_{2} \mathrm{O}$ (Aldrich, purity $\geq 99 \%$ ), $\mathrm{NiSO}_{4} \cdot 6 \mathrm{H}_{2} \mathrm{O}$ (Aldrich, purity $\geq 98 \%$ ), $\mathrm{MnSO}_{4} \cdot \mathrm{H}_{2} \mathrm{O}$ (Aldrich, purity $\geq 99 \%$ ).

The solution of $0.1 \mathrm{~mol} \mathrm{~L}^{-1}$ sulfuric acid was prepared by diluting appropriate amount of pure $\mathrm{H}_{2} \mathrm{SO}_{4}$ (Aldrich, purity $=97 \%$ ) in deionized water (resistivity $=18 \mathrm{Mohms}$ ).

The composition of the synthetic solution was representative of leach solutions of NMC111 cathodic materials, i.e., $2.60 \mathrm{~g} \mathrm{~L}^{-1}$ lithium(I), $7.88 \mathrm{~g} \mathrm{~L}^{-1}$ cobalt(II), $8.01 \mathrm{~g} \mathrm{~L}^{-1}$ nickel(II), $4.40 \mathrm{~g} \mathrm{~L}^{-1}$ manganese(II) and $51.45 \mathrm{~g} \mathrm{~L}^{-1}$ sulfate [19]. The $\mathrm{pH}$ of the aqueous solutions containing the metal salts was adjusted at $\mathrm{pH}=2.83$ by adding $0.1 \mathrm{~mol} \mathrm{~L}^{-1}$ sulfuric acid to find the best compromise between the faradic yield and the lithium extraction efficiency.

\subsection{Setup}

The ED setup reported in Figure 1a was composed of a DC power (Microlab, Parsippany, NJ, USA), a 2 L-anode solution reservoir, a 2 L-dilute reservoir fed by the leach solution, a $2 \mathrm{~L}$-concentrate reservoir, a $2 \mathrm{~L}$-cathode solution reservoir and four peristaltic pumps (Masterflex L/S model 77250-62, assembled by Parmer Instrument Company, Vernon Hills, IL, USA). The flow rate was fixed at $100 \mathrm{~mL} \mathrm{~min}^{-1}$ for all experiments. Neosepta ${ }^{\circledR}$ AMX (Astom Company, Tokyo, Japan) and Selemion CSO (Asahi Glass Company, Tokyo, Japan) were used as anionic exchange membrane (AEM) and cationic exchange membrane (CEM), respectively. The surface area of these membranes was equal to 10 or $40 \mathrm{~cm}^{2}$. A Neosepta ${ }^{\circledR}$ monovalent-selective cationic exchange membrane (provided by Eurodia Industrie, Pertuis, France) was also used (surface area $=10$ or $40 \mathrm{~cm}^{2}$ ). Prior to experiments, the cationic exchange membranes and the anionic exchange membranes were immersed into an aqueous solution containing $0.1 \mathrm{~mol} \mathrm{~L}^{-1} \mathrm{Li}_{2} \mathrm{SO}_{4}$ and deionized water for $24 \mathrm{~h}$, respectively. However anionic exchange membranes were immersed in deionized water for $24 \mathrm{~h}$.

The ED performances were studied by calculating the faradic efficiency $\left(\mathrm{R}_{\mathrm{f}}\right)$, the permselectivity index for $\mathrm{Li}(\mathrm{I})$ toward $\mathrm{M}(\mathrm{P}(\mathrm{Li} / \mathrm{M}))$ and the cations flux $\left(J_{i}\right)$, defined as follows:

$$
\mathrm{R}_{\mathrm{f}}(\%)=100 \frac{\mathrm{zF}}{\mathrm{I} \Delta \mathrm{t}} \Delta \mathrm{n}
$$

where $\Delta \mathrm{n}(\mathrm{mol})$ denotes the moles number of cations transported through the membrane and $\mathrm{F}$ the Faraday constant $\left(96,487 \mathrm{C} \mathrm{mol}^{-1}\right)$; $\mathrm{z}$ is the ion valence, I (A) is the applied current and $\Delta \mathrm{t}(\mathrm{s})$ is the operation time of electrodialysis.

$$
\mathrm{P}(\mathrm{Li} / \mathrm{M})=\left(\frac{[\mathrm{Li}]_{\mathrm{c}}}{[\mathrm{M}]_{\mathrm{c}}}\right) /\left(\frac{[\mathrm{Li}]_{0}}{[\mathrm{M}]_{0}}\right)
$$

where $[\mathrm{Li}]_{\mathrm{C}}$ and $[\mathrm{M}]_{\mathrm{C}}$ are the lithium and metal concentrations in the recovery compartment at time t. $[\mathrm{Li}]_{0}$ and $[\mathrm{M}]_{0}$ are the initial lithium and metal concentrations in the central compartment, respectively.

$$
J_{i}\left(\mathrm{~mol} \mathrm{~m}^{-2} \mathrm{~s}^{-1}\right)=\frac{\Delta n_{i}}{A N t}
$$

where $\Delta n_{i}$ is the mole number of cation $i$ transferred from central to recovery compartment. $A\left(\mathrm{~m}^{2}\right)$ is the active area of membrane and $N$ is the number of membranes' pairs in electrodialysis cell ( $N=1$ for all our experiments). 
(a)

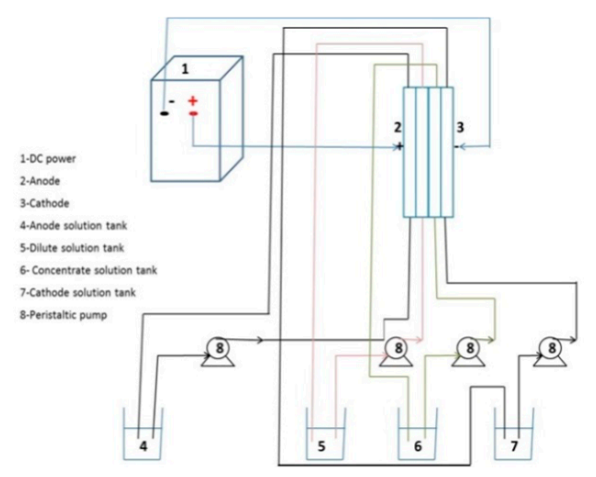

(b)

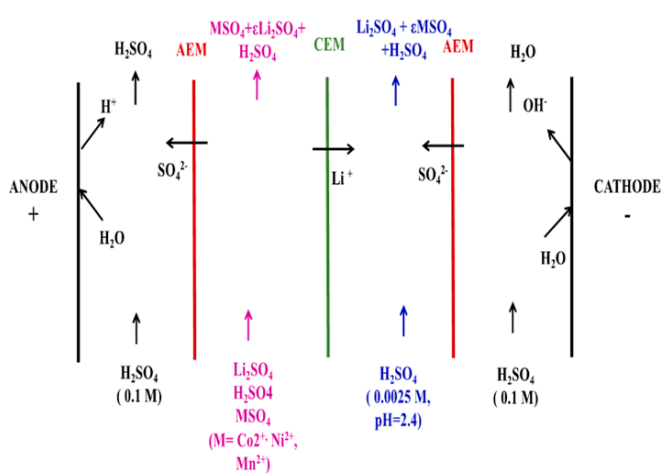

(c)

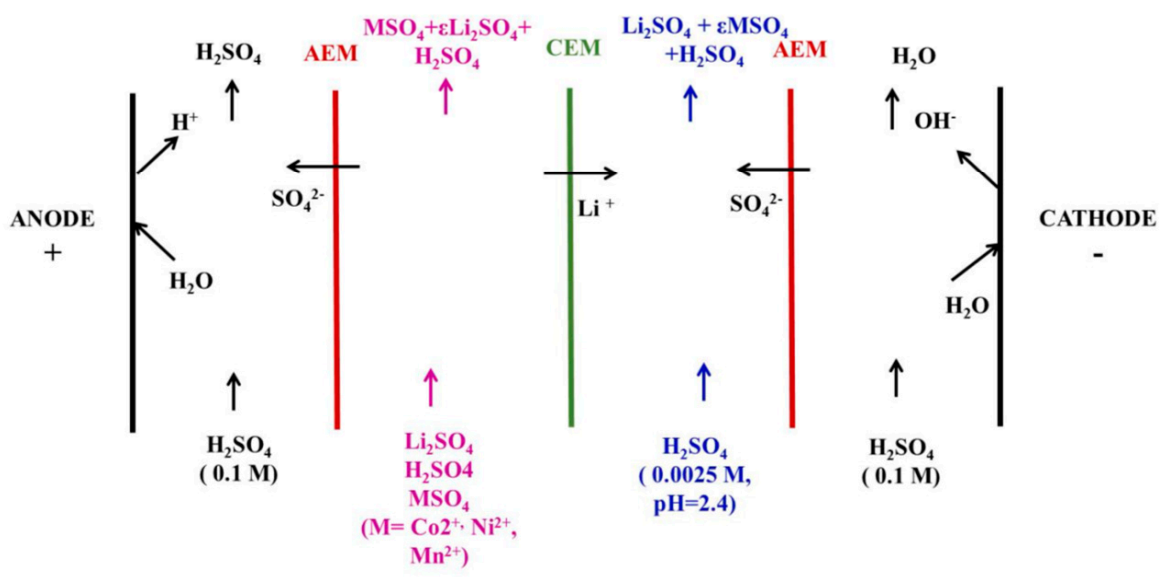

Figure 1. (a) ED setup; (b) Configuration 1 of the electrodialysis cell and (c) Configuration 2 of the electrodialysis cell.

\subsection{Elemental Analysis}

Lithium, cobalt, nickel and manganese concentrations were determined using induced coupled plasma-optical emission spectrometry (ICP-OES, ICAP 6000 Series). Determination of metal concentrations in the aqueous phases were performed at the following wavelengths: $610.362 \mathrm{~nm}$ and $670.784 \mathrm{~nm}$ for lithium, $238.892 \mathrm{~nm}, 237.862 \mathrm{~nm}$ and $231.160 \mathrm{~nm}$ for cobalt, $221.647 \mathrm{~nm}, 216.556 \mathrm{~nm}$ and $230.300 \mathrm{~nm}$ for nickel, and $259.373 \mathrm{~nm}, 294.920 \mathrm{~nm}$ and $293.930 \mathrm{~nm}$ for manganese. Seven standards containing 5, 10, 20, 25, 50, 80 and $100 \mathrm{mg} \mathrm{L}^{-1}$ lithium, nickel, cobalt and manganese diluted in $0.1 \mathrm{~mol} \mathrm{~L}^{-1} \mathrm{H}_{2} \mathrm{SO}_{4}$ or $0.0025 \mathrm{~mol} \mathrm{~L}^{-1}$ $\mathrm{H}_{2} \mathrm{SO}_{4}$ were prepared by using a multi-elemental standard solution containing $1 \mathrm{~g} \mathrm{~L}^{-1}$ lithium, $1 \mathrm{~g} \mathrm{~L}^{-1}$ nickel, $1 \mathrm{~g} \mathrm{~L}^{-1}$ cobalt and $1 \mathrm{~g} \mathrm{~L}^{-1}$ manganese dissolved in $5 \%$ nitric acid (SCP science).

\section{Results and Discussion}

\subsection{Effect of Current Density on Membrane Selectivity}

The ED configuration displayed in Figure $1 \mathrm{~b}$ was used to investigate the selectivity of the CSO membrane and the Neosepta ${ }^{\circledR}$ monovalent-selective cationic exchange membrane for lithium(I) toward cobalt(II), nickel(II) and manganese(II). Figure 2 shows the variation of lithium(I), cobalt(II), nickel(II) and manganese(II) concentrations in the recovery compartment as a function of time. 


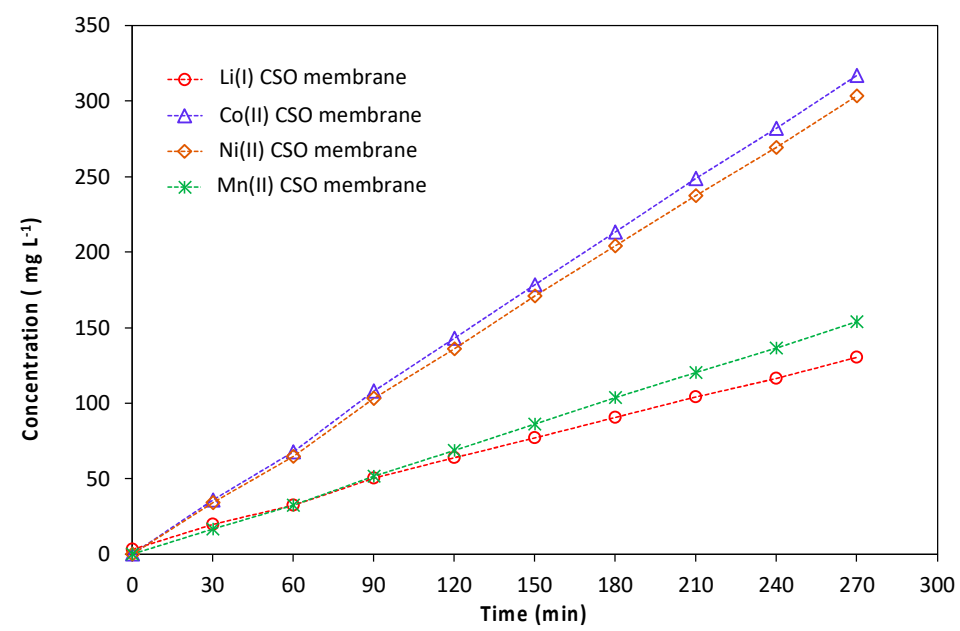

(a)

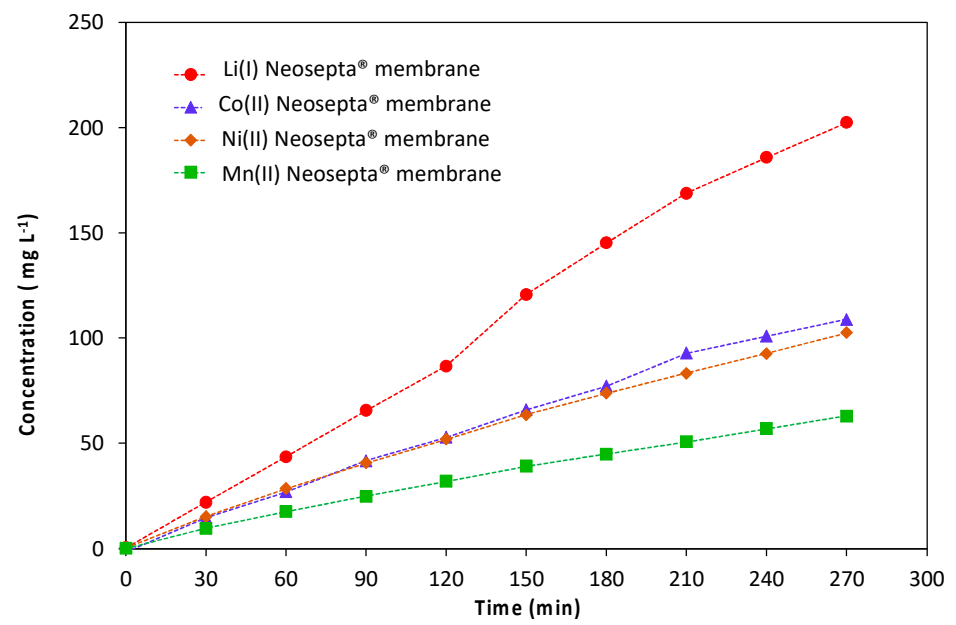

(b)

Figure 2. Lithium(I), cobalt(II), nickel(II) and manganese(II) concentrations in the recovery compartment as a function of time by using the ED configuration 1 displayed in Figure $1 \mathrm{~b}$ with (a) Selemion CSO cationic exchange membrane, and (b) Neosepta ${ }^{\circledR}$ monovalent-selective cationic exchange membrane $\left(\mathrm{j}=12.5 \mathrm{~mA} \mathrm{~cm}^{-2}\right.$; Flowrate $=100 \mathrm{~mL} \mathrm{~min}^{-1}$ in all compartments; Anodic and cathodic solutions: $0.1 \mathrm{M} \mathrm{H}_{2} \mathrm{SO}_{4}$ ( $\mathrm{pH}$ in the leaching solution decreased from 2.8 to 2.1 but it remained almost constant and equal to 1 in the recovery solution).

The metal transfer rate from the central compartment to the cathodic compartment follows the following order (i) $\mathrm{Co}(\mathrm{II}) \approx \mathrm{Ni}$ (II) $>\mathrm{Mn}$ (II) $>\mathrm{Li}$ (I) in the presence of the CSO membranes and (ii) $\mathrm{Li}(\mathrm{I})>\mathrm{Co}(\mathrm{II}) \approx \mathrm{Ni}(\mathrm{II})>\mathrm{Mn}$ (II) in the presence of the Neosepta ${ }^{\circledR}$ monovalentselective cationic exchange membranes. Thus, Figure 2 showed that both membranes cannot separate nickel(II) and cobalt(II) because these elements exhibit similar physicochemical properties. The Neosepta ${ }^{\circledR}$ monovalent-selective cationic exchange membrane exhibits higher selectivity for lithium(I) toward divalent cations than the CSO membrane.

Table 1 shows that the lithium(I) molar flux is 1.6 times higher with the Neosepta ${ }^{\circledR}$ monovalent-selective cationic exchange membrane than with the CSO membrane. Conversely, the total flux of divalent cations is 2.8 times lower. 
Table 1. Permselectivity index for lithium towards the $\mathrm{M}(\mathrm{P}(\mathrm{Li} / \mathrm{M}))$, faradic efficiency $\left(\mathrm{R}_{\mathrm{f}}\right)$, and cation flux $\left(J_{i}\right.$ in mol m$\left.~^{-2} \mathrm{~s}^{-1}\right)$ of $i=$ lithium(I), cobalt(II), nickel(II) and manganese(II) after 270 min of electrodialysis when the CSO membrane or the Neosepta ${ }^{\circledR}$ monovalent-selective cationic exchange membrane was used in the ED cell displayed in Figure $1 \mathrm{~b}$. Current density $=12.5 \mathrm{~mA} \mathrm{~cm}{ }^{-2}$; Flow rate $=100 \mathrm{~mL} \mathrm{~min}^{-1}$ in all compartments; Anodic and cathodic solutions: $0.1 \mathrm{M} \mathrm{H}_{2} \mathrm{SO}_{4} ; \mathrm{pH}=2.8$ in the leaching solution to increase the faradic efficiency.

\begin{tabular}{ccccccc}
\hline & \multicolumn{2}{c}{ CSO Membrane } & & \multicolumn{3}{c}{$\begin{array}{c}\text { Neosepta }{ }^{\circledR} \text { Monovalent Selective } \\
\text { Cationic Exchange Membrane }\end{array}$} \\
\hline $\mathbf{M}$ & $J_{i}$ & $\mathbf{R}_{\mathbf{f}}(\mathbf{\%})$ & $\mathbf{P}(\mathbf{L i} / \mathbf{M})$ & $J_{i}$ & $\mathbf{R}_{\mathbf{f}}(\%)$ & $\mathbf{P}(\mathbf{L i} / \mathbf{M})$ \\
\hline $\mathrm{Li}^{+}$ & $53.3 \times 10^{-5}$ & 40.8 & - & $84.6 \times 10^{-5}$ & 67.1 & - \\
$\mathrm{Co}^{2+}$ & $15.6 \times 10^{-5}$ & 23.9 & 1.25 & $5.4 \times 10^{-5}$ & 8.2 & 5.6 \\
$\mathrm{Ni}^{2+}$ & $15.0 \times 10^{-5}$ & 22.9 & 1.30 & $5.1 \times 10^{-5}$ & 7.8 & 6.1 \\
$\mathrm{Mn}^{2+}$ & $8.1 \times 10^{-5}$ & 12.4 & 1.4 & $3.3 \times 10^{-5}$ & 5.1 & 5.4 \\
\hline
\end{tabular}

The high selectivity of the Neosepta ${ }^{\circledR}$ monovalent-selective cationic exchange membrane results in higher faradic efficiency for lithium(I) and higher permselectivity indexes for lithium(I) with respect to the different divalent cations. The permselectivity index for the Neosepta ${ }^{\circledR}$ monovalent-selective cationic exchange membrane $\left(\mathrm{P}_{\mathrm{Li} / \mathrm{Co}}=5.6\right)$ is slightly lower than those reported in the work of Afifah et al. (2018) [17], i.e., $\mathrm{P}(\mathrm{Li} / \mathrm{Co})=6.75$ at a flowrate of $15 \mathrm{~L} \mathrm{~h}^{-1}$ and for a voltage of $3 \mathrm{~V} /$ Cell with a pack containing 5 pairs of monovalent selective membranes PC-MVA/PC-MVK (initial lithium(I) and cobalt(II) concentration $=100 \mathrm{mg} \mathrm{L}^{-1}$ and $300 \mathrm{mg} \mathrm{L}^{-1}$, respectively) against $\mathrm{P}(\mathrm{Li} / \mathrm{Co})=5.6$ in this study. However, the value reported in our work regarding the permselectivity index for lithium(I) toward manganese(II) is greater than that obtained by Chan et al. [13] $(\mathrm{P}(\mathrm{Li} / \mathrm{Mn})=5.4$ in the present study against $\mathrm{P}(\mathrm{Li} / \mathrm{Mn})=2.81$ at a flowrate of $45 \mathrm{~L} \mathrm{~h}^{-1}$ and for a voltage of $6 \mathrm{~V} /$ Cell with a pack containing 2 pairs of standard anionic membranes PCA PC 400D and 2 Neosepta ${ }^{\circledR}$ CMS cationic membranes, which are selective towards monovalent cations).

The ED configuration reported in Figure 1c was used under the operating conditions gathered in Table 2 (cell 2) to study the impact of the current density on the electrodialysis performance by using the Neosepta ${ }^{\circledR}$ monovalent-selective cationic exchange membrane. This configuration exhibits an additional compartment between the cathodic compartment and the anodic compartment. This compartment was fed with $0.0025 \mathrm{~mol} \mathrm{~L}^{-1} \mathrm{H}_{2} \mathrm{SO}_{4}$ $(\mathrm{pH}$ 2.4). This new configuration delays possible metal precipitation phenomena into the membranes that might occur after several hours of experiments.

Table 2. Faradic efficiencies $\left(\mathrm{R}_{\mathrm{f}}\right)$ for the transfer of lithium(I), cobalt(II), nickel(II) and manganese(II), and permselectivity indexes $\mathrm{P}(\mathrm{Li} / \mathrm{M})$ at current density $\mathrm{j}=10 \mathrm{~mA} \mathrm{~cm}{ }^{-2}, 12.5 \mathrm{~mA} \mathrm{~cm}{ }^{-2}$ et $15 \mathrm{~mA}$ $\mathrm{cm}^{-2}$ after performing electrodialysis during $240 \mathrm{~min}$ (Flowrate $=100 \mathrm{~mL} \mathrm{~min}^{-1}$ in all compartments, Neosepta ${ }^{\circledR}$ monovalent-selective cationic exchange membrane).

\begin{tabular}{|c|c|c|c|c|c|c|}
\hline \multicolumn{3}{|c|}{$\mathrm{j}=10 \mathrm{~mA} \mathrm{~cm}^{-2}$} & \multicolumn{2}{|c|}{$\mathrm{j}=12.5 \mathrm{~mA} \mathrm{~cm}^{-2}$} & \multicolumn{2}{|c|}{$\mathrm{j}=15 \mathrm{~mA} \mathrm{~cm}^{-2}$} \\
\hline & $R_{f}(\%)$ & P (Li/M) & $R_{f}(\%)$ & $P(\mathrm{Li} / \mathrm{M})$ & $R_{f}(\%)$ & P (Li/M) \\
\hline $\mathrm{Li}^{+}$ & 67.0 & - & 68.0 & - & 55.1 & - \\
\hline $\mathrm{Co}^{2+}$ & 7.9 & 5.9 & 7.1 & 5.5 & 9.7 & 4.1 \\
\hline $\mathrm{Ni}^{2+}$ & 7.8 & 6.1 & 7.2 & 5.6 & 10.0 & 4.0 \\
\hline $\mathrm{Mn}^{2+}$ & 4.8 & 5.8 & 4.3 & 5.4 & 5.5 & 4.3 \\
\hline
\end{tabular}

Figure 3 shows the influence of the current density on the metal concentrations in the recovery compartment as a function of time for $4 \mathrm{~h}$. The increase of the current density from $10 \mathrm{~mA} \mathrm{~cm}^{-2}$ to $12.5 \mathrm{~mA} \mathrm{~cm}^{-2}$ did not influence the transfer of the divalent metals, i.e., cobalt(II), nickel(II) and manganese(II), whereas lithium(I) transfer is slightly affected. The membrane selectivity toward monovalent cations decreased with increasing current as the permselectivity indexes decreased progressively with increasing current density (Table 2). 
(a) Lithium

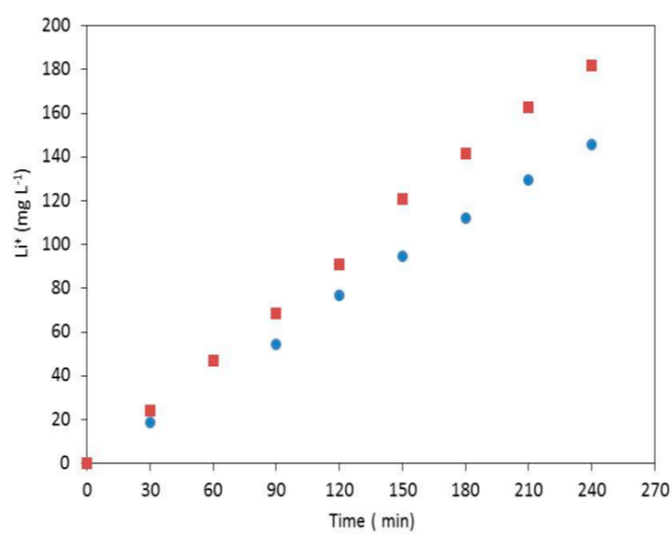

(c) nickel

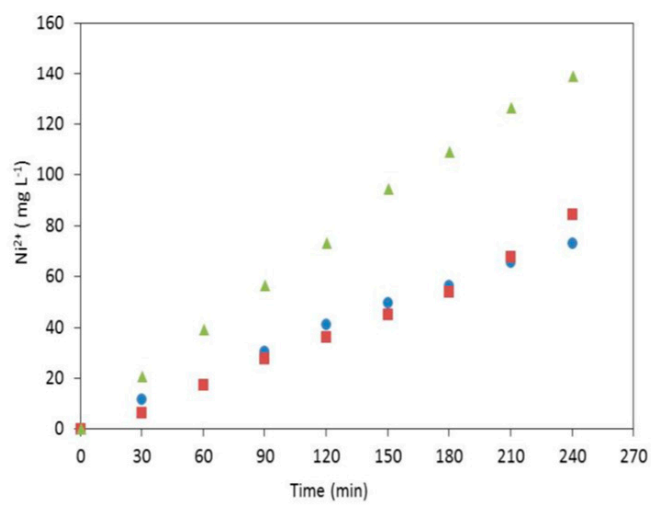

(b) Cobalt

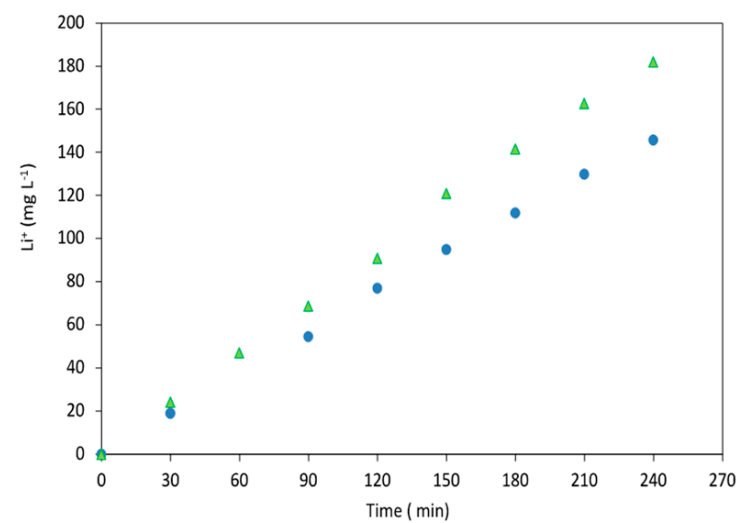

(d) Manganese

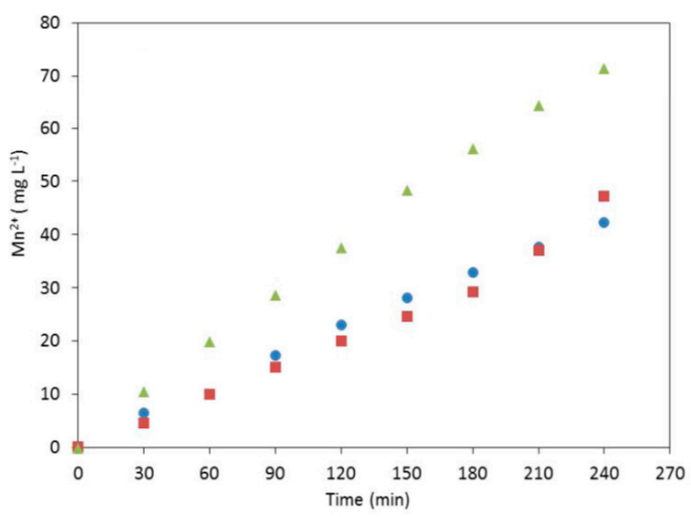

Figure 3. Evolution of metal concentrations in the recovery compartment as a function of time at $\mathrm{j}=10 \mathrm{~mA} \mathrm{~cm}^{-2}$ (blue circle), $12.5 \mathrm{~mA} \mathrm{~cm}^{-2}$ (red square) and $15 \mathrm{~mA} \mathrm{~cm}{ }^{-2}$ (green triangle) with the ED configuration 2 reported in Figure $1 \mathrm{c}$ (Anodic and cathodic compartments $=0.1 \mathrm{M} \mathrm{H}_{2} \mathrm{SO}_{4}$; concentrate solution $=0.0025 \mathrm{M} \mathrm{H}_{2} \mathrm{SO}_{4}\left(\sigma=2.27 \mathrm{mS} \mathrm{cm}^{-1}, \mathrm{pH}=2.4\right)$ when $\mathrm{j}=10 \mathrm{~mA} \mathrm{~cm}{ }^{-2} ; \mathrm{Li}_{2} \mathrm{SO}_{4}$ $\left(5 \mathrm{~g} \mathrm{~L}^{-1} \mathrm{Li}^{+}\right)$in $0.0025 \mathrm{M} \mathrm{H}_{2} \mathrm{SO}_{4}\left(\sigma=38.83 \mathrm{mS} \mathrm{cm}^{-1} \mathrm{pH}=2.82\right)$ when $\mathrm{j}=12.5 \mathrm{~mA} \mathrm{~cm}^{-2} ; 0.0025 \mathrm{M}$ $\mathrm{H}_{2} \mathrm{SO}_{4}\left(\sigma=2.24 \mathrm{mS} \mathrm{cm}^{-1}, \mathrm{pH}=2.3\right)$ when $\mathrm{j}=15 \mathrm{~mA} \mathrm{~cm}^{-2}$; Neosepta ${ }^{\circledR}$ monovalent-selective cationic exchange membrane; The $\mathrm{pH}$ value in the leaching solution decreased from 2.8 to 2.3 but it remained almost constant and equal to 2.3 in the concentrate for all current densities).

The sums of the faradic efficiencies related to metal transport remained almost constant, i.e., $87 \%$ at $10 \mathrm{~mA} \mathrm{~cm}^{-2}$ and $12.5 \mathrm{~mA} \mathrm{~cm}^{-2}$. Conversely, the faradic efficiency diminished down to $80.3 \%$ when the current density was increased to $15 \mathrm{~mA} \mathrm{~cm}^{-2}$, likely due to water splitting (water dissociation onto the membrane surface), which was responsible for an increase of the protons transfer.

Given that the limiting current density was equal to $j_{\mathrm{lim}}=18.9 \mathrm{~mA} \mathrm{~cm}^{-2}$, a current density of $15 \mathrm{~mA} \mathrm{~cm}^{-2}$ corresponding to $80 \%$ of the limiting current density was applied [20]. A decrease of the faradic yield of lithium(I) and an increase of the faradic yield of divalent cations were observed when the current density was close to the limiting current density at the expense of lithium transfer selectivity.

\subsection{Metal Precipitation into the Membranes}

No precipitation was observed into the Neosepta ${ }^{\circledR}$ monovalent-selective cationic exchange membrane when the electrodialysis lasted less than $270 \mathrm{~min}$. Conversely, a greenish precipitate was observed inside the Neosepta ${ }^{\circledR}$ monovalent-selective cationic exchange 
membrane after performing electrodialysis during $810 \mathrm{~min}(13.5 \mathrm{~h})$ at $12.5 \mathrm{~mA} \mathrm{~cm}^{-2}$ followed by $5 \mathrm{~h}$ at $15 \mathrm{~mA} \mathrm{~cm}^{-2}$ (configuration 2 in Figure 1c). Precipitation occurred faster when the concentration ratio between lithium(I) and divalent cations ( $\mathrm{Ni}(\mathrm{II}), \mathrm{Co}(\mathrm{II}), \mathrm{Mn}(\mathrm{II})$ ) in the leachate compartment decreased as it was also observed when full lithium-selective membranes were used in ED (divalent cation concentrations remained constant as they were not transferred from the leachate compartment into the recovery compartment, and lithium(I) concentration decreased due to their efficient transfer across the membrane). For instance, a greenish precipitate was observed after $20 \mathrm{~min}$ of electrodialysis at $10 \mathrm{~mA} \mathrm{~cm}{ }^{-2}$ when the leach solution contained initially $0.5 \mathrm{~g} \mathrm{~L}^{-1}$ lithium(I) and $7.88 \mathrm{~g} \mathrm{~L}^{-1}$ cobalt(II), $8.09 \mathrm{~g} \mathrm{~L}^{-1}$ nickel(II) and $4.40 \mathrm{~g} \mathrm{~L}^{-1}$ manganese(II). Precipitation occurred despite the low values of $\mathrm{pH}$ into the leachate compartment $(\mathrm{pH}=2.8)$ and the recovery compartment $(\mathrm{pH}=2.3)$. The increase of the local $\mathrm{pH}$ and the local concentration of the divalent cations at the membrane surface may be responsible for precipitation. The local increase of $\mathrm{pH}$ can be explained by the water splitting at the membrane surface when the current density reaches the limiting value. The high local concentration of divalent cations onto the membrane surface can be explained by the high selectivity of the membrane.

Therefore, the precipitation phenomena could be avoided by mastering the current density so that its value remains lower than the limiting current density. Table 3 gathers the limiting current densities deduced from Figure 4 by the Cowan and Brown method [21].

The limiting current was reached when lithium(I) concentration at the membrane surface was equal to zero. In the case of an ideal lithium(I) selective membrane, the current cannot be transported by the divalent cations, and therefore, only the protons generated by water splitting at the membrane surface can transport the current. Furthermore, water splitting may affect the selectivity of the electro-membrane process as reported by Melnikov et al. [22]. The control of the current density is particularly important to regulate the fluxes of salt ions and water splitting products (hydrogen and hydroxyl ions). The water splitting led to the formation of hydroxide ions at the membrane surface, which were responsible for an increase of the local $\mathrm{pH}$ at the surface membrane. Both the accumulation of divalent cations at the membrane surface and the local increase of $\mathrm{pH}$ may lead to metal hydroxide precipitation at the membrane surface.

Table 3. Limiting current density ( $\mathrm{j}_{\text {lim }}$ ) determined by the Cowan and Brown method (Cowan and Brown, 1959) by using the ED configuration 2 in Figure 1c (Flowrate $=100 \mathrm{~mL} \mathrm{~min}^{-1}$, Neosepta ${ }^{\circledR}$ monovalent-selective cationic exchange membrane, Surface area of the membrane $=10 \mathrm{~cm}^{2}$ ).

\begin{tabular}{|c|c|c|c|}
\hline $\begin{array}{l}\text { Initial Composition } \\
\text { of the Feed Solution }\end{array}$ & $\begin{array}{l}\text { Initial Ionic Conductivity in } \\
\text { the Feed Solution }\left(\mathrm{mS} \mathrm{cm}^{-1}\right)\end{array}$ & $\begin{array}{l}\text { Initial } \mathrm{pH} \text { in the } \\
\text { Feed Solution }\end{array}$ & $\underset{\left(\mathrm{mA} \mathrm{cm}^{-2}\right)}{\mathrm{j}_{\lim }}$ \\
\hline $\begin{array}{l}{\left[\mathrm{Li}^{+}\right]=0.025 \mathrm{M}} \\
{\left[\mathrm{H}^{+}\right]=0.025 \mathrm{M}}\end{array}$ & 8.10 & 1.83 & 21.1 \\
\hline $\begin{array}{c}{\left[\mathrm{Li}^{+}\right]=0.05 \mathrm{M}} \\
{\left[\mathrm{H}^{+}\right]=0.025 \mathrm{M}}\end{array}$ & 9.17 & 1.86 & 23.3 \\
\hline $\begin{array}{c}{\left[\mathrm{Li}^{+}\right]=0.025 \mathrm{M}} \\
{\left[\mathrm{H}^{+}\right]=0.025 \mathrm{M}} \\
{\left[\mathrm{Ni}^{2+}\right]=0.025 \mathrm{M}}\end{array}$ & 9.67 & 1.90 & 12.8 \\
\hline $\begin{array}{c}{\left[\mathrm{Li}^{+}\right]=0.374 \mathrm{M}} \\
{\left[\mathrm{Co}^{2+}\right]=0.133 \mathrm{M}} \\
{\left[\mathrm{Ni}^{2+}\right]=0.136 \mathrm{M}} \\
{\left[\mathrm{Mn}^{2+}\right]=0.08 \mathrm{M}}\end{array}$ & 38.28 & 2.82 & 18.9 \\
\hline
\end{tabular}




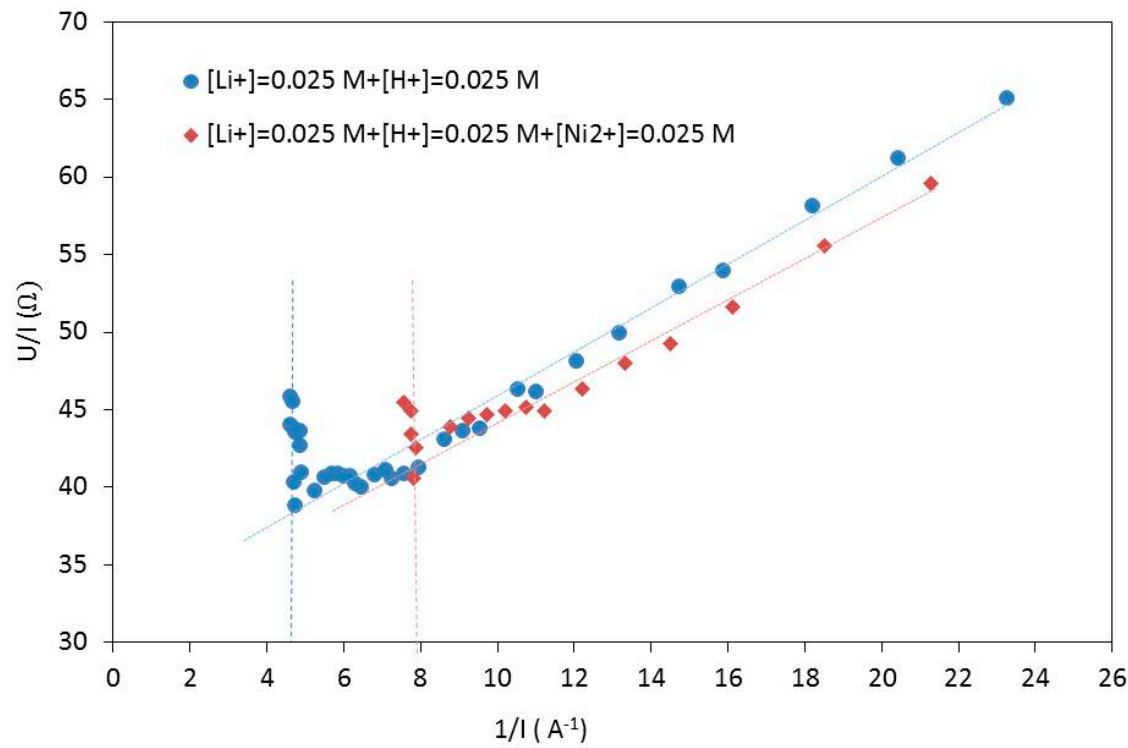

Figure 4. Determination of the limiting current density by using the ED configuration 2 reported in Figure $1 \mathrm{c}$ (Flow rate $=100 \mathrm{~mL} \mathrm{~min}^{-1}$; cathodic and anodic compartments $=0.1 \mathrm{~mol} \mathrm{~L}^{-1} \mathrm{H}_{2} \mathrm{SO}_{4}$; Feed solution: $\left[\mathrm{Li}^{+}\right]=\left[\mathrm{H}^{+}\right]=0.025 \mathrm{~mol} \mathrm{~L}^{-1}$ or $\left[\mathrm{Li}^{+}\right]=\left[\mathrm{H}^{+}\right]=\left[\mathrm{Ni}^{2+}\right]=0.025 \mathrm{~mol} \mathrm{~L}^{-1}$, Neosepta ${ }^{\circledR}$ monovalent-selective cationic exchange membrane).

The concentration profiles of lithium(I) and divalent cations in the boundary layer at the vicinity of the membrane depicted in Figure 5 depends on the difference in transport numbers between the bulk and into the membrane.

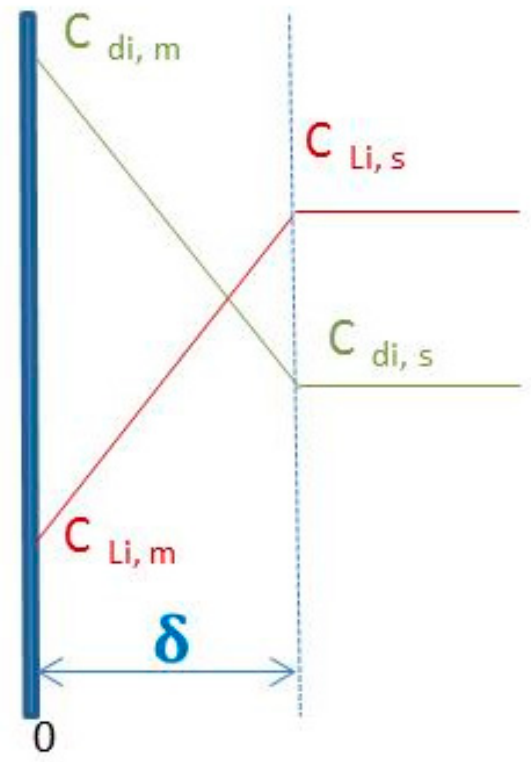

\section{Monovalent selective}

\section{cation exchange membrane}

Figure 5. Schematic representation of the concentration profiles of lithium(I) ions and divalent cations near the cation-selective membrane $\left(\delta\right.$ : thickness of diffusion boundary layer, $\mathrm{C}_{\mathrm{Li}, \mathrm{s}}$ : lithium concentration in solution, $\mathrm{C}_{\mathrm{Li}, \mathrm{m}}$ : lithium concentration at the membrane surface, $\mathrm{C}_{\mathrm{div}, \mathrm{s}}$ : divalent cation concentration in solution, $\mathrm{C}_{\mathrm{div}, \mathrm{m}}$ : divalent cation concentration at the membranes' surface). 
In the bulk, the transport number of the species $i$ corresponds to the fraction of current transported by that species according to the following equation:

$$
t_{i}=\frac{u_{i} Z_{i} C_{i}}{\sum_{i} u_{i} Z_{i} C_{i}}
$$

where $u_{i}$ is the electrophoretic mobility in $\mathrm{m}^{2} \mathrm{~V}^{-1} \mathrm{~s}^{-1}$ of the ion $i$ of charge $Z_{i}$ and concentration $C_{i}$.

The transport number of lithium(I) is thus affected by the concentration of the divalent cations in the solution. In the case of an ideal selective membrane toward monovalent cations, the current is carried by the monovalent cations (lithium(I) and protons in the present work) whereas the divalent cations do not contribute to the current:

$$
\begin{gathered}
\sum_{\begin{array}{c}
\text { monovalent } \\
\text { cations }
\end{array}} \overline{t_{i}}=1 \\
\sum_{\substack{\text { divalent } \\
\text { cations }}} \overline{t_{i}}=0
\end{gathered}
$$

The transport number of monovalent cations in the membrane was found to be independent on the divalent cation concentration. Thus, the transport numbers of the monovalent cations were not influenced by the divalent cations in the case of an ideal selective membrane. Conversely, the transport numbers of the monovalent cations in solution were influenced by the presence of divalent cations in solution. The difference between the transport numbers of the monovalent cations in the membrane and in the solution increases with the concentration ratio of divalent/monovalent cations in solution. Such an increase contributes to the decrease of the monovalent cation concentration at the vicinity of the membrane, and thus, contributes to the decrease of the limiting current.

The present work evidenced that an increase of the concentration ratio of divalent/monovalent cations in solution was responsible for a decrease of the limiting current density and an increase of precipitation risks into the lithium-selective membrane. Likewise, the decrease of the limiting current density may arise from the slow transport of monovalent cations due to electrostatic repulsion onto the membrane surface caused by the presence of a layer of divalent cations.

Therefore, the use of highly selective membranes in ED requires to determine the value of the limiting current density in operando to check that the current density is always lower than the limiting current density. Monitoring the ionic conductivity in the diluate is then not sufficient and the main challenge is therefore to monitor the limiting current over time [23-25].

Providing that the current density in the electrodialysis cell could be managed to be lower than the limiting current density, such an electrodialysis technology could be included in a more global flowsheet involving other hydrometallurgical unit operations such as solvent extraction and precipitation as illustrated in Figure 6. After leaching the blackmass in sulfuric acid in the presence of hydrogen peroxide [26], cobalt(II), nickel(II) and manganese(II) could be extracted and separated by solvent extraction by using Cyanex ${ }^{\circledR} 272$ as extractant [27]. The remaining stream containing lithium(I) and traces of manganese(II), nickel(II) and cobalt(II) could be afterwards refined by using electrodialysis to produce high-grade lithium salt by precipitation. 


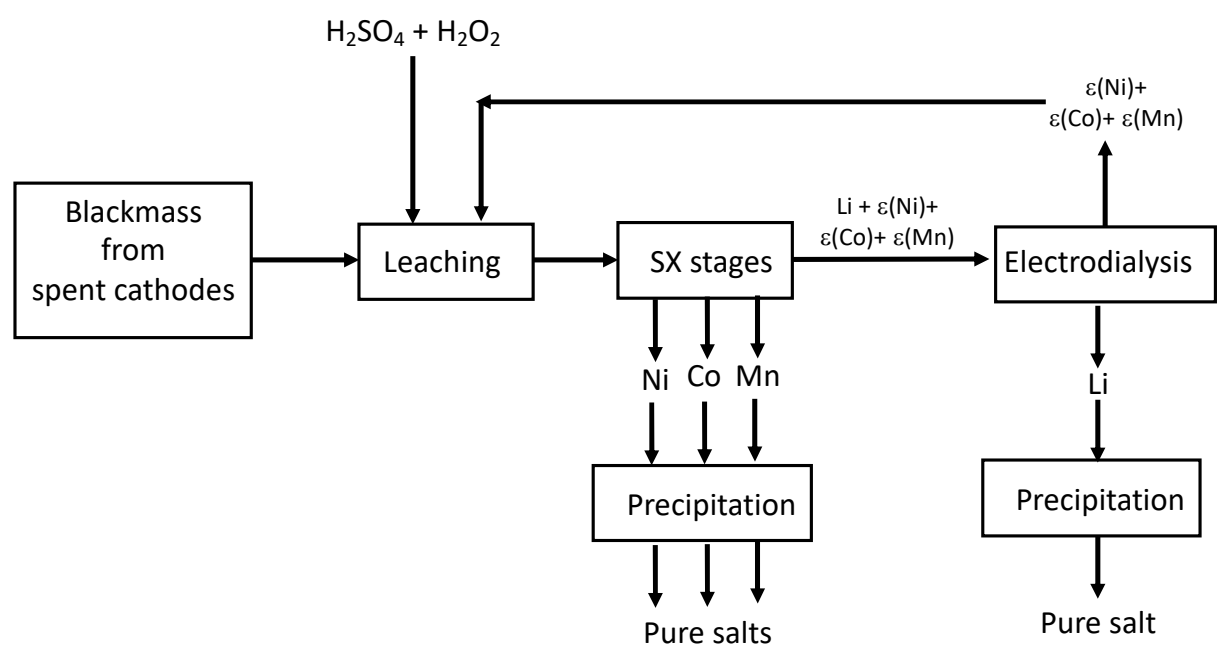

Figure 6. General concept of the implementation of ED unit operation in hydrometallurgical processes for the production of high-grade lithium salts.

\section{Conclusions}

This paper showed that electrodialysis is an interesting technology to extract selectively and concentrate lithium(I) toward nickel(II), cobalt(II) and manganese(II) from acidic sulfate media. Therefore, this technology could be used in lithium-ion battery recycling processes. More interestingly, electrodialysis could be implemented at the end of the process to remove traces of nickel(II), cobalt(II) and manganese(II) from the lithium solution after cobalt(II), nickel(II) and manganese(II) recovery by liquid-liquid extraction. Thus, electrodialysis could be advantageously used to concentrate the lithium stream and to produce high-grade lithium salts after precipitation with sodium carbonate.

However, there remains a few challenges to solve before implementing electrodialysis technologies in lithium-ion battery recycling, especially when high-selective membranes toward lithium(I) are used. In fact, the difference in transport properties between lithium(I) and divalent cations, i.e., cobalt(II), nickel(II) and manganese(II), through a monovalent ionselective membrane are responsible for precipitation of the divalent cations into the porosity of the membrane since the limiting current decreases significantly during electrodialysis. The main challenge is therefore to monitor the limiting current over time in order to keep the current value lower than the limiting current.

Author Contributions: Conceptualization, A.C. and L.M.; methodology, L.M., S.G., F.L. and A.C.; validation, S.G., L.M., F.L. and A.C.; formal analysis, S.G., L.M. and A.C.; investigation, S.G., L.M. and A.C.; writing - original draft preparation, S.G., L.M. and A.C.; writing-review and editing, L.M. and A.C.; supervision, L.M. and A.C.; project administration, A.C.; funding acquisition, A.C. All authors have read and agreed to the published version of the manuscript.

Funding: This research was funded by the French National Research Agency through the national program "Investissementsd'avenir" with the reference ANR-10-LABX-21-RESSOURCES21 and ADEME under the reference $1902 \mathrm{C} 0073$.

Data Availability Statement: The data presented in this study are available on request from the corresponding author.

Conflicts of Interest: The authors declare no conflict of interest.

\section{References}

1. Chagnes, A.; Pospiech, B. A brief review on hydrometallurgical technologies for recycling spent lithium-ion batteries. J. Chem. Technol. Biotechnol. 2013, 88, 1191-1199. [CrossRef]

2. Yang, B.; Wang, J.; Cao, P.; Zhu, T.; Shu, H.; Chen, J.; Zhang, J.; Zhu, J. Classification, summarization and perspectives on state-of-charge estimation of lithium-ion batteries used in electric vehicles: A critical comprehensive survey. J. Energy Storage 2021, 39, 1-26. [CrossRef] 
3. International Energy Agency. Global EV Outlook 2021-Accelerating Ambitions Despite the Pandemic; International Energy Agency: Paris, France, 2021.

4. Swain, B. Recovery and recycling of lithium: A review. Sep. Purif. Technol. 2017, 172, 388-403. [CrossRef]

5. Chagnes, A.; Swiatowska, J. (Eds.) Lithium Process Chemistry: Resources, Extractions, Batteries and Recycling; Elsevier: Amsterdam, The Netherlands, 2015; 304p, ISBN 978-0-12-801417-2. [CrossRef]

6. Gmar, S.; Chagnes, A. Recent advances on electrodialysis for the recovery of lithium from primary and secondary resources. Hydrometallurgy 2019, 189, 105-124. [CrossRef]

7. Kwon, O.S.; Sohn, I. Fundamental thermokinetic study of a sustainable lithium-ion battery pyrometallurgical recycling process. Resour. Conserv. Recy. 2020, 158, 1-12. [CrossRef]

8. Chen, X.; Chen, Y.; Zhou, T.; Liu, D.; Hu, H.; Fan, S. Hydrometallurgical recovery of metal values from sulfuric acid leaching liquor of spent lithium-ion batteries. Waste. Manag. 2015, 38, 349-356. [CrossRef]

9. Jung, J.C.Y.; Sui, P.C.; Zhang, J. A review of recycling spent lithium-ion battery cathode materials using hydrometallurgical treatments. J. Energy Storage 2021, 35, 1-21. [CrossRef]

10. Bahaloo Horeh, N.; Mousavi, S.M.; Shojaosadati, S.A. Bioleaching of valuable metals from spent lithium-ion mobile phone batteries using Aspergillus niger. J. Power Sources 2016, 320, 257-266. [CrossRef]

11. Othman, E.A.; Van der Ham, A.G.J.; Miedema, H.; Kersten, S.R.A. Recovery of metals from spent lithium-ion batteries using ionic liquid [P8888][Oleate]. Sep. Purif. Technol. 2020, 252, 117435. [CrossRef]

12. Giorgio Schiavi, P.; Altimari, P.; Branchi, M.; Zanoni, R.; Simonetti, G.; Assunta Navarra, M.; Pagnanelli, F. Selective recovery of cobalt from mixed lithium-ion battery wastes using deep eutectic solvent. Chem. Eng. J. 2021, 417, 129249. [CrossRef]

13. Chan, K.H.; Malik, M.; Azimi, G. Separation of lithium, nickel, manganese and cobalt from waste lithium-ion batteries using electrodialysis. Resour. Conserv. Recycl. 2022, 178, 106076. [CrossRef]

14. Strathmann, H. Ion-Exchange Membrane Separation Processes; Membrane Science and Technology Series, 9; Elsevier: Amsterdam, The Netherlands, 2004; 360p.

15. Ankoliya, D.; Mudgal, A.; Sinha, M.K.; Davies, P.; Licon, E.; Alegre, R.R.; Patel, V.; Patel, J. Design and optimization of electrodialysis process parameters for brackish water treatment. J. Clean. Prod. 2021, 319, 1-11. [CrossRef]

16. Lizuka, A.; Yamashita, Y.; Nagasawa, H.; Yamasaki, A.; Yanagisawa, Y. Separation of lithium and cobalt from waste lithium-ion batteries via bipolar membrane electrodialysis coupled with chelation. Sep. Purif. Technol. 2013, 113, 33-41.

17. Afifah, D.N.; Ariyanto, T.; Supranto Prasetyo, I. Separation of lithium ion from lithium-cobalt mixture using electrodialysis monovalent selective ion exchange membrane. Eng. J. 2018, 22, 165-179. [CrossRef]

18. Song, Y.; Zhao, Z. Recovery of lithium from spent lithium-ion batteries using precipitation and electrodialysis techniques. Sep. purif. Technol. 2018, 206, 335-342. [CrossRef]

19. Chen, C.W.; Ho, H.J. Recovery of valuable metals from lithium-ion batteries NMC cathode waste materials by hydrometallurgical methods. Metals 2018, 8, 321. [CrossRef]

20. Balmann, H.R.; Casademont, E. Electrodialyse. Techniques de l'Ingénieur 2006, 2840. [CrossRef]

21. Cowan, D.A.; Brown, J.H. Effect of turbulence on limiting current in electrodialysis cells. Ind. Eng. Chem. 1959, 51, 1445-1448. [CrossRef]

22. Melnikov, S.; Bondarev, D.; Nosova, E.; Melnikova, E.; Zabolotskiy, V. Water Splitting and Transport of Ions in Electromembrane System with Bilayer Ion-Exchange Membrane. Membranes 2020, 10, 346. [CrossRef] [PubMed]

23. Nakayama, A.; Sano, Y.; Bai, X.; Tado, K. Aboundary layer analysis for determination of the limiting current density in an electrodialysis desalination. Desalination 2017, 404, 41-49. [CrossRef]

24. Cerva, M.L.; Gurreri, L.; Tedesco, M.; Cipollina, A.; Ciofalo, M.; Tamburini, A.; Micale, G. Determination of limiting current density and current efficiency in electrodialysis units. Desalination 2018, 445, 138-148. [CrossRef]

25. Ying, J.; Luo, M.; Jin, Y.; Yu, J. Selective separation of lithium from high Mg/Li ratio brine using single- stage and multi-stage selective electrodialysis processes. Desalination 2020, 492, 1-11. [CrossRef]

26. Zhou, L.F.; Yang, D.; Du, T.; Gong, H.; Luo, W.B. The Current Process for the Recycling of Spent Lithium Ion Batteries. Front. Chem. 2020, 8, 578044. [CrossRef] [PubMed]

27. Nguyen, T.H.; Lee, M.S. A Review on the Separation of Lithium Ion from Leach Liquors of Primary and Secondary Resources by Solvent Extraction with Commercial Extractants. Processes 2018, 6, 55. [CrossRef] 